\title{
Complex pattern of immunoglobulin $\mu$ gene expression in normal and transgenic mice: nonoverlapping regulatory sequences govern distinct tissue specificities
}

\author{
Thomas Jenuwein and Rudolf Grosschedl \\ Howard Hughes Medical Institute and Departments of Microbiology and Biochemistry, University of California, San \\ Francisco, California 94143 USA
}

\begin{abstract}
Analysis of normal mice and transgenic mice carrying a rearranged immunoglobulin $\mu$ gene revealed a more complex tissue-specific pattern of $\mu$ gene expression than anticipated from previous observations. Expression of the endogenous $\mu$ locus and the $\mu$ transgene was detected both in lymphoid tissues and in skeletal muscle. Analysis of the expression pattern of $\mu$ transgenes containing intragenic deletions or point mutations in binding sites for Oct transcription factors (OCTA sites) indicated that distinct regulatory sequences control lymphoid- and muscle-specific $\mu$ gene expression. Consistent with previous transfection experiments, $\mu$ gene expression in lymphoid tissues is dependent on the intragenic enhancer and the OCTA site in the promoter. However, neither of these regulatory sequences is required for $\mu$ gene expression in skeletal muscle that is governed by a muscle-specific control region located 3' of the enhancer. An "off-state" of the $\mu$ transgene was observed only in liver and embryonal fibroblasts, whereas enhancer-dependent $\mu$ transgene expression was detected at low levels in other nonlymphoid tissues. From these data we suggest a model for the regulation of tissue-specific $\mu$ gene expression in which a "ubiquitous" competence for basal transcription is up-regulated in lymphoid and muscle tissues by distinct cell type-specific regulatory sequences and down-regulated in liver and fibroblastic cells by putative negative sequence elements.
\end{abstract}

[Key Words: Immunoglobulin $\mu$ gene; cell type-specific gene expression; OCTA sites; transgenic mice]

Received November 21, 1990; revised version accepted February 25, 1991.

Cell type-specific patterns of gene expression represent genetically stable differences in the transcriptional state of genes. These include both the differences between an "on-state" and an "off-state" of gene expression and the quantitative difference between on-states. Cell type-specific gene expression has been shown to be governed by transcriptional regulators that are specific to one or a few cell types and by differences in the "balance" of positively and negatively acting "ubiquitous" transcription factors (for review, see Herskowitz 1989; Mitchell and Tiian 1989).

Immunoglobulin genes are expressed and assembled from multiple gene segments by DNA rearrangement specifically in B lymphocytes (for review, see Blackwell and Alt 1988). Gene transfer of rearranged $\mu$ immunoglobulin heavy-chain ( $\operatorname{IgH}$ ) genes into the mouse germ line (Grosschedl et al. 1984; Storb et al. 1986; Nussenzweig et al. 1987) and into cultured lymphoid and fibroblastic cell lines (Gillies et al. 1983; Neuberger 1983; Grosschedl and Baltimore 1985) indicated that lym- phoid-specific expression can be uncoupled from gene rearrangement. Lymphoid-specific transcription of rearranged IgH genes was shown to be governed both by the variable region $\left(\mathrm{V}_{\mathrm{H}}\right)$ promoter and by an intragenic enhancer (Banerii et al. 1983; Gillies et al. 1983; Grosschedl and Baltimore 1985; Mason et al. 1985). Regulatory sequence elements residing in the promoter and the enhancer have been identified by mutational analysis in tissue culture transfection assays (for review, see Calame 1989; Libermann and Baltimore 1991) and by genomic "footprinting" in vivo (Ephrussi et al. 1985).

The nucleotide sequence 5'-ATGCAAAT, which is referred to as the OCTA site, is present in both the $V_{H}$ promoter and the intragenic enhancer of rearranged $\mu$ heavy-chain immunoglobulin genes. The OCTA site in the promoter confers a 5- to 10-fold higher transcriptional activity upon a heterologous promoter in B-lymphoid versus fibroblastic cell lines (Wirth et al. 1987). This sequence has been demonstrated to interact in vitro with a family of nuclear factors, collectively termed Oct 
proteins or octamer transcription factors (OTFs) (Singh et al. 1986; Staudt et al. 1986; Fletcher et al. 1987; Scheidereit et al. 1987; Schöler et al. 1989). One member of this family, termed Oct-2, can be detected in high abundance in lymphoid B-cell lines, in lower abundance in several lymphoid T-cell lines, and in some nonlymphoid tissues such as brain and kidney, but is absent from fibroblastic cell lines and most nonlymphoid tissues (Staudt et al. 1986; Schöler et al. 1989; Cockerill and Klinken 1990). The OCTA site has also been shown to interact in vitro with the ubiquitous Oct-1 transcription factor (Singh et al. 1986; Fletcher et al. 1987; Scheidereit et al. 1987; LeBowitz et al. 1988; Johnson et al. 1990|. Oct-1, however, appears to be less effective than Oct-2 at stimulating transcription from a promoter containing an OCTA-related site in transfection assays (Tanaka and Herr 1990). The heptanucleotide sequence 5 '-CTC-ATGA, termed Hepta site, has been identified as an additional low-affinity binding site for Oct-1 and Oct2 in vitro (Landolfi et al. 1988; Kemler et al. 1989; Poellinger et al. 1989). The Hepta site is found in many but not all $\mathrm{V}_{\mathrm{H}}$ promoters $5^{\prime}$ to the OCTA site, which appears to be necessary for occupancy of the Hepta site by Oct proteins (Poellinger et al. 1989).

The intragenic $\mu$ enhancer encompasses an OCTA site and other factor-binding sites, termed the $\mu \mathrm{B}$ site, the $\mathrm{E}$ box, the $\mu \mathrm{E} 1-\mu \mathrm{E} 5$ motifs, and enhancer core sequences (Ephrussi et al. 1985; Peterson et al. 1986; Sen and Baltimore 1986; Lenardo et al. 1987; Araki et al. 1988). The $\mathrm{E}$ box and the $\mu \mathrm{E} 5 / \mathrm{E} 2$ and $\mu \mathrm{E} 3$ sites have been shown to interact with ubiquitous factors in vitro (Murre et al. 1989; Beckmann et al. 1990; Henthorn et al 1990; Roman et al. 1990). The $\mu \mathrm{B}$ site is, to date, the only other site in the enhancer that generates a B-cell-specific "footprint" in nuclear extracts and is implicated in contributing to B-cell specificity of enhancer function (Libermann et al. 1990; Nelsen et al. 1990). The cell typespecific function of the $\mu$ enhancer in lymphoid versus fibroblastic cells was also shown to involve negative regulation because deletions of nucleotide sequences within and adjacent to the enhancer allow, at least in part, for $\mu$ enhancer function in fibroblastic cells (Kadesch et al. 1986; Imler et al. 1987; Weinberger et al. 1988; Scheuermann and Chen 1989l.

In this study we introduced rearranged wild-type and mutated $\mu$ genes into the mouse germ line to examine the role of Oct factor-binding sites and other regulatory sequences in the context of the intact gene and the whole animal. The analysis of the expression of various $\mu$ transgenes in lymphoid tissues was consistent with previous tissue culture transfection assays. However, the tissue-specific pattern of transgene expression was more complex than anticipated. Instead of a simple on-state in lymphoid tissues and an off-state in nonlymphoid tissues, the $\mu$ transgene was found to be expressed at a high level both in lymphoid tissues and in skeletal muscle. This "dual" tissue specificity was also demonstrated for the endogenous $\mu$ locus. Furthermore, $\mu$ transgene expression at a low level was detected in many but not all nonlymphoid tissues. We show that this complex pat- tern of $\mu$ gene expression is governed by nonoverlapping regulatory sequences of distinct tissue specificities.

\section{Results \\ $\mu$ Gene expression in lymphoid tissues and skeletal muscle}

Transgenic mice carrying rearranged $\mu$ heavy-chain genes were generated by microinjection of vector-free DNA into fertilized eggs and surgical reimplantation into foster mothers (see Materials and methods). Expression of a rearranged wild-type $\mu$ transgene was examined by analyzing total RNA from various tissues of the mouse line 4 for the presence of correctly initiated $\mu_{T}$ transgene transcripts (Fig. 1A). As expected, S1 nuclease protection assays of tissue RNA indicated abundant $\mu_{T}$ transcripts in lymphoid tissues (spleen and thymus). The size of the protected fragment (62 nucleotides) indicated faithful initiation at the site mapped for this promoter in a rearranged endogenous gene /Grosschedl and Baltimore 1985). Surprisingly, strong expression of the $\mu$ transgene was also observed in skeletal muscle. In addition, lowlevel expression was detected in kidney, brain, salivary gland, lung, and heart. This expression pattern was confirmed by the analysis of mice from two additional lines carrying the wild-type $\mu$ transgene (see Figs. 3 and 5, below). To demonstrate that the $\mu_{\mathrm{T}}$ transcripts detected in skeletal muscle are not derived from contaminating $B$ lymphocytes, we examined the RNA for the presence of endogenous $\kappa$ immunoglobulin transcripts by hybridization with a $c_{\kappa}$ constant region probe. No $\kappa$ transcripts were detectable in the RNA from skeletal muscle. However, salivary gland and lung contained $\kappa$ transcripts, indicating some contamination with B lymphocytes (Fig. 1A, middle). To demonstrate that the quantity and integrity of the RNA is similar for each sample, the $18 \mathrm{~S}$ rRNA was stained with ethidium bromide (Fig. 1A, bottom). From these data we conclude that the $\mu$ transgene is selectively expressed in lymphoid and skeletal muscle tissues and that the $\mu_{\mathrm{T}}$ transcripts in both tissues initiate at the same site in the $\mathrm{V}_{\mathrm{H}}$ promoter.

To examine whether this unexpected expression of the transgene in skeletal muscle was also true for the endogenous $\mu$ locus, we analyzed RNA from tissues of a normal C57BL6 mouse by S1 nuclease protection assays with a $c_{\mu}$ constant region probe. This probe allows the detection of transcripts from both rearranged and unrearranged $\mu$ genes. Indeed, $c_{\mu}$ transcripts were detected in spleen, thymus, and also in skeletal muscle (Fig. 1B). The number of $c_{\mu}$ transcripts in thymus and skeletal muscle was significantly lower than in spleen, most likely because of a lack of complete gene rearrangement (Kemp et al. 1980). Like the $\mu_{\mathrm{T}}$ transcripts, the endogenous $\mu$ transcripts in skeletal muscle also appear to be generated by transcription of the $\mu$ gene in this tissue rather than by lymphocyte contamination by the following arguments: First, RNA from skeletal muscle did not contain any detectable $\kappa$ transcripts (Fig. 1B, bottom). Second, the analysis of size-fractionated transcripts from skeletal 


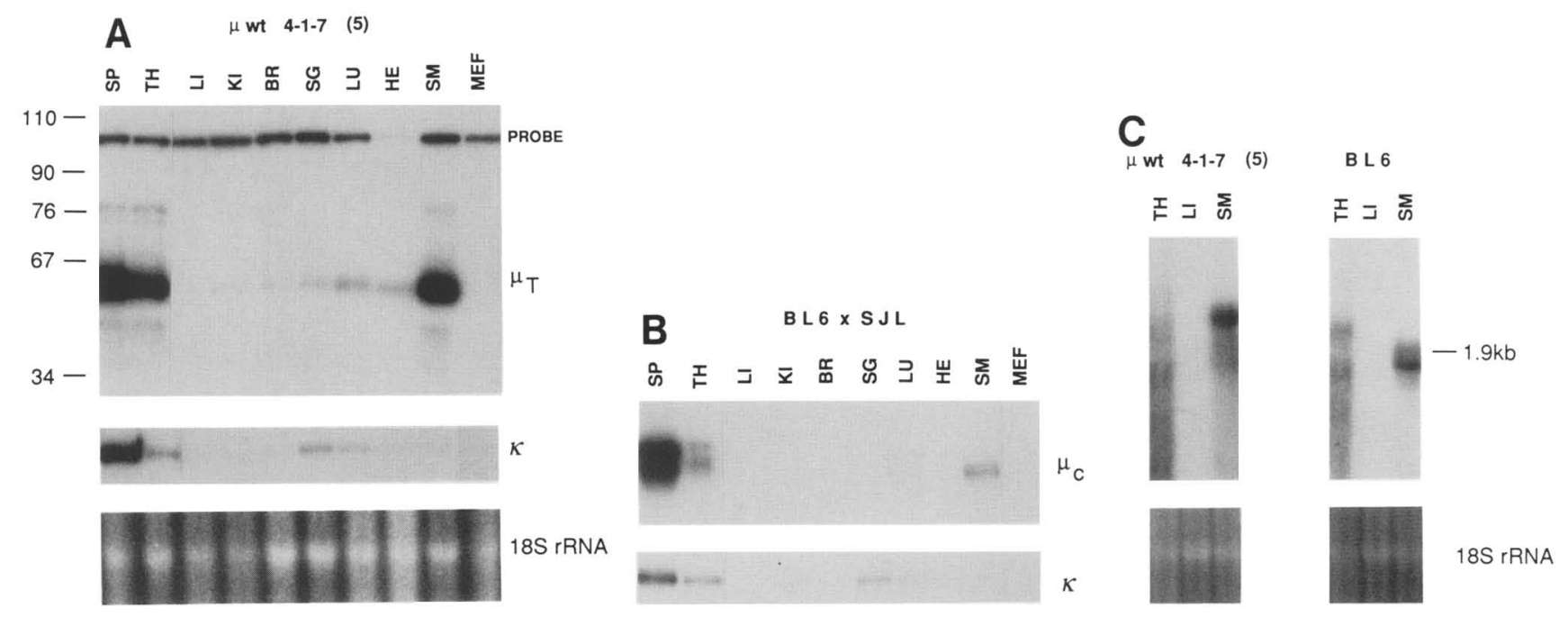

Figure 1. "Dual" tissue specificity of expression of the wild-type $\mu$ transgene and the endogenous $\mu$ gene. $(A)(T o p)$ S1 nuclease protection assay detecting transgenic $\mu_{\mathrm{T}}$ transcripts in total RNA from spleen (SP), thymus (TH), liver (LI), kidney (KI), brain (BR), salivary gland (SG), lung (LU), heart (HE), skeletal muscle (SM), and mouse embryonal fibroblasts (MEF) of the transgenic mouse 4-1-7 carrying five copies of the rearranged wild-type $\mu$ gene. Total RNA $(3 \mu \mathrm{g})$ was hybridized with a 5 '-end-labeled variable $\mathrm{V}_{\mathrm{H}}$ region DNA probe specific for the $\mu$ transgene and treated with S1 nuclease, and the protected fragment was fractionated by electrophoresis through denaturing polyacrylamide gels and visualized by autoradiography. (Middle) S1 nuclease protection assay of $3 \mu \mathrm{g}$ of total RNA with a $5^{\prime}$ end-labeled $c_{\kappa}$ constant region probe detecting endogenous $\kappa$ transcripts. (Bottom) Ethidium bromide-stained 18S rRNA. (B) (Top) S1 nuclease protection assay with a $5^{\prime}$ end-labeled $c_{\mu}$ constant region probe detecting endogenous $\mu$ transcripts in $6 \mu \mathrm{g}$ of total RNA from tissues (same as in $A$ ) of a nontransgenic C57BL6 $\times$ SJL mouse. (Bottom) S1 nuclease protection assay detecting endogenous $k$ transcripts in $6 \mu \mathrm{g}$ of total RNA. $(C)$ RNA blot analysis of transgenic and endogenous $\mu$ transcripts. Twelve micrograms of total RNA from thymus (TH), liver (LI), and skeletal muscle (SM) was fractionated by electrophoresis through an agarose-formaldehyde gel, transferred to a nylon filter, cross-linked by UV radiation, hybridized with a ${ }^{32}$ p-labeled nick-translated $\mathrm{c}_{\mu}$ constant region DNA probe, and visualized by autoradiography. The position and size $(1.9 \mathrm{~kb})$ of the $18 \mathrm{~S}$ rRNA are indicated. (Bottom) Ethidium bromide-stained $18 \mathrm{~S}$ rRNA photographed under UV light prior to the transfer to the nylon filter.

muscle indicated that the size of these endogenous $\mu$ transcripts is $1.8 \mathrm{~kb}$ (Fig. 1C). This is different from both the 2.4- and 2.7-kb $\mu$ mRNA found in spleen and the multiple $c_{\mu}$ transcripts derived from the unrearranged or incompletely rearranged $\mu$ gene in thymus (Fig. 1C; Nelson et al. 1983). The endogenous $\mu$ transcripts in skeletal muscle also differ from the transgenic $\mu_{\mathrm{T}}$ transcripts, indicating that the endogenous $\mu$ gene is not rearranged in skeletal muscle (Fig. 1C). Expression of the endogenous $\mu$ locus in skeletal muscle was detected in other mouse strains as well, although the level of expression varied over a broad range. In C57BL6, SJL, and C3H mice, endogenous $c_{\mu}$ transcripts in skeletal muscle were present at a level approximately fivefold lower than that in thymus; whereas in skeletal muscle from BALB/c mice, the $c_{\mu}$ transcripts were barely detectable /data not shown).

Because the expression of the rearranged $\mu$ transgene in several nonlymphoid tissues is $\sim 50$-fold lower than in skeletal muscle, the sensitivity of the $\mathrm{Sl}$ protection assay is not sufficient to determine whether this low-level expression of the $\mu$ transgene reflects a similar transcriptional state of the endogenous gene or whether the transgene lacks regulatory sequences that prevent expression of the endogenous $\mu$ gene in these tissues. Taken together, these data show that both the endogenous $\mu$ gene and rearranged $\mu$ transgenes exhibit a previously un- known dual tissue specificity and are expressed in lymphoid and muscle tissues.

\section{Role of Oct-binding sites for $\mu$ gene expression in lymphoid tissues and skeletal muscle}

The high level of $\mu$ gene expression in lymphoid tissues and in skeletal muscle raised the question as to whether both types of tissues utilize the same set or a distinct set of regulatory sequences in the $\mu$ gene. Because the Octbinding sites have been shown previously to be involved in lymphoid-specific gene expression, we were particularly interested in comparing the role of the OCTA sites for transgene expression in lymphoid and skeletal muscle tissues.

We generated transgenic mice carrying rearranged $\mu$ genes with point mutations in Oct-binding sites (Fig. 2). The expression of the transgenes was analyzed in founders that were shown to transmit the transgene in a Mendelian manner or in progeny to avoid the analysis of animals mosaic for the transgene. The wild-type $\mu$ transgene was expressed in spleen of three independent mouse lines at high levels (Fig. 3, top). The level of expression appeared to be fairly independent of the chromosomal site of the integrated transgene. As an internal control for the relative number of B lymphocytes in each tissue sample and to demonstrate the integrity of the 


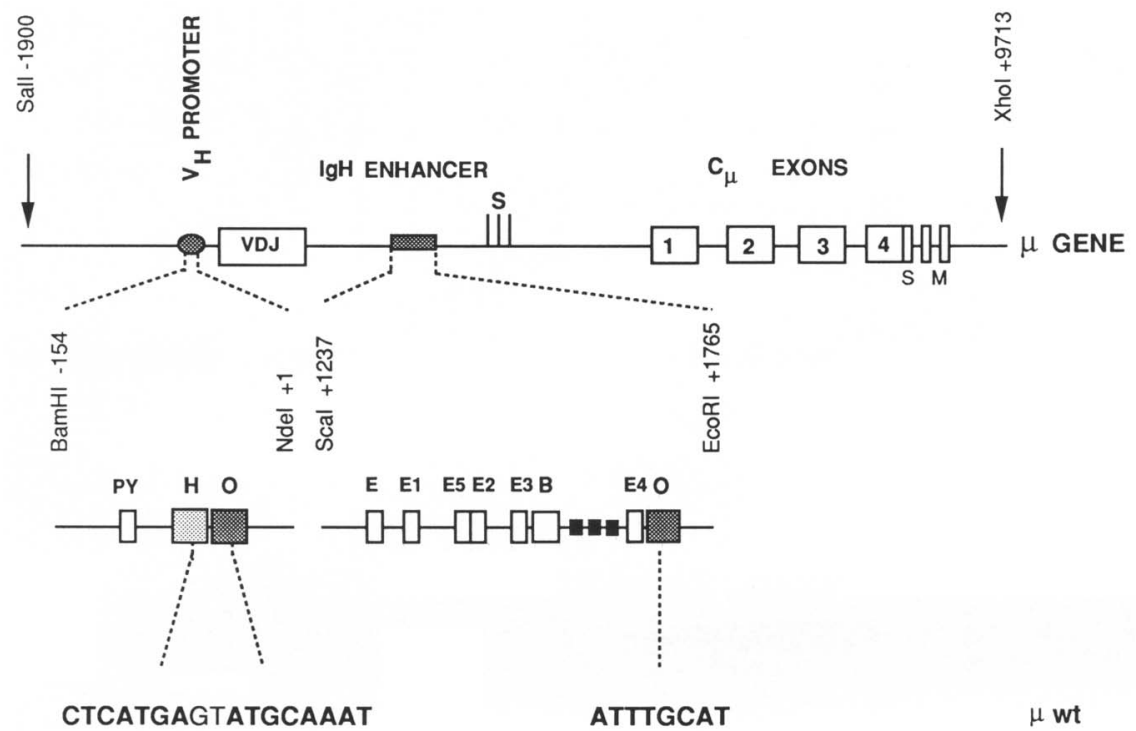

aTCtTGA
ATTTGCAT

$\mu w$
ATaTGaAT

ATaTGaAT
ATtCAtAT

ATtCATAT

Figure 2. Structure of the rearranged wildtype $\mu$ gene and of point mutations in Octbinding sites. The $\mathrm{V}_{\mathrm{H}}$ variable region promoter and the intragenic enhancer of the rearranged $\mu$ gene are represented as a stippled circle and stippled bar, respectively. The rearranged VDJ variable region isolated from the hybridoma 17.2.25 (Loh et al. 1983) and the $c_{\mu}$ constant region exons are indicated by open boxes with $S$ and $M$ representing the exons specifying the secreted and membrane-bound forms of the $\mu$ polypeptide. Some of the restriction sites used for the construction of point mutants are shown with their corresponding nucleotide position relative to the start site of transcription as +1 . Factor-binding sites in promoter and enhancer are depicted as boxes. The octamer 5'-ATGCAAAT (OCTA site) is the high-affinity binding site for the Oct proteins and is represented by the stippled box $O$. The heptamer low-affinity Oct-binding site in the promoter is indicated as the stippled box $\mathrm{H}$. Other factor-binding sites or functionally defined regulatory sequences, termed $\mathrm{E}$ box, pyrimidine-rich sequence (Py), and E1-E5 motifs (for review, see Libermann and Baltimore 1990), are represented as open boxes. Enhancer core motifs are shown as solid boxes. Below, the nucleotide sequences of the octamer $|O|$ and heptamer $(\mathrm{H})$ Oct-binding sites are shown for the wild-type $(w t)$ gene. Point
tated transgenes carrying one or two altered mutations in these nucleotide sequences are indicated in lowercase letters, and the mutated transgenes carrying one or two altered
factor-binding sites are designated at right. For microinjection of the rearranged $\mu$ genes into fertilized C57BL $6 \times$ SIL $F_{2}$ mouse eggs, the plasmids were cut with SalI and XhoI and the $\mu$ gene inserts were isolated.

RNA preparation, we determined the number of transcripts of the B-lymphocyte-specific endogenous $m b-1$ gene (Sagakuchi et al. 1988 ) or $\kappa$ gene. Similar numbers of $m b-1$ or $\mathrm{k}$ transcripts were detected in the individual tissue samples (data not shown). In addition to spleen, we analyzed lymphoid-specific expression of the transgene in thymus for the following reasons: First, thymus contains primarily cells that represent the $\mathrm{T}$-cell lineage. Second, $T$ cells do not synthesize endogenous $\mu$ protein because of a lack of complete immunoglobulin gene rearrangement (Kurosawa et al. 1981; Reth and Alt 1984). As a consequence, expression of the transgene cannot be influenced by endogenous $\mu$ protein. Third, the abundance of Oct- 2 in several T-cell lines is substantially less than that observed in B-cell lines (Cockerill and Klinken 1990). Despite these differences, we find, in agreement with previous observations (Grosschedl et al. 1984), that the wild-type $\mu$ transgene is equally well expressed in both lymphoid tissues (Fig. 3, middle).

Mutation of the OCTA site in the promoter $\left(\mathrm{O}_{\mathrm{P}}\right)$ reproducibly decreased the number of specific $\mu$ transcripts in both spleen and thymus by a factor of 20-30 (Fig. 3, top and middle). The $\mathrm{O}_{\mathrm{P}}{ }^{-} \mathrm{O}_{\mathrm{E}}{ }^{-}$double mutation of the OCTA sites in both promoter and enhancer did not further reduce the number of specific $\mu_{T}$ transcripts, suggesting either functional redundancy of the OCTA site in the enhancer or a functional interaction between both OCTA sites. To examine these possible interpretations, we analyzed transgenic mice that carry a $\mu$ transgene with a single mutation in the OCTA site of the enhancer $\left(\mathrm{O}_{\mathrm{E}}{ }^{-}\right)$. Four of five mouse lines expressed the mutated transgene at a similar level as the wild-type gene. The fifth mouse line, 642, expressed the $\mathrm{O}_{\mathrm{E}}{ }^{-}$transgene at a 10 -fold lower level, indicating some variability in the transcriptional effect of this mutation. Taken together, however, these results indicate that expression of the $\mu$ transgene in lymphoid tissues is virtually independent of the OCTA site in the enhancer but is to a large extent dependent on the OCTA site in the promoter. The low-affinity Oct-binding site in the promoter $\left(\mathrm{H}_{\mathrm{P}}\right)$ is also dispensable for transgene expression in lymphoid tissues because the $\mathrm{H}_{\mathrm{P}}{ }^{-}$mutation did not significantly decrease the number of $\mu_{T}$ transcripts in two mouse lines.

In skeletal muscle these mutations have little or no transcriptional effects (Fig. 3, bottom). Expression of the $\mathrm{O}_{\mathbf{P}}{ }^{-}$mutant transgene is indistinguishable from the wild-type gene in two mouse lines (817 and 801$)$ and only fourfold lower in line 811 . These data indicate that the OCTA site in the promoter is virtually dispensable for the high-level expression of the $\mu$ transgene in skeletal 
Figure 3. Octa-dependent and Octa-independent promoter function in lymphoid tissues and skeletal muscle. S1 nuclease protection assay detecting transgenic $\mu_{\mathrm{T}}$ transcripts in $3 \mu \mathrm{g}$ of total RNA from spleen, thymus, and skeletal muscle of transgenic mice. The 62 -bp protected fragment corresponding to correctly initiated transcripts is indicated with $\mu_{\mathrm{T}}$. Individual mouse lines carrying a particular transgene are grouped according to the microinjected gene. The first, second, and third number indicate the mouse line, the generation, and the individual mouse, respectively. The letter $F$ after the number of the mouse line indicates the founder animal. Only founders who transmitted the transgene in a Mendelian manner were included in the analysis. The number in parentheses refers to the approximate copy number of the transgene as determined by DNA blot analysis. For the analysis of transgene expression, the mice were sacrificed between the ages of 8 and 12 weeks. The integrity and quantity of each RNA preparation from spleen and thymus were confirmed by $\mathrm{S} I$ nuclease protection assays with DNA probes that detect endogenous $m b$-1 (Sagakuchi et al. 1988) or $\kappa$ transcripts (data not shown).

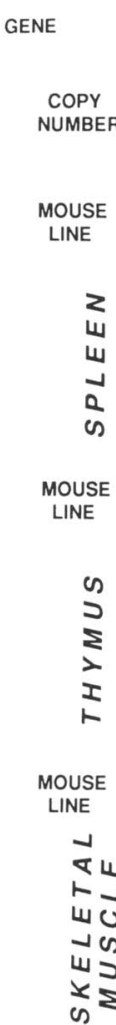

muscle. The mutation of the $\mathrm{H}_{\mathrm{P}}$ site in the promoter had no transcriptional effect in mouse line 716 ; however, it decreased transgene expression by a factor of 10 in mouse line 717. The small number of $\mathrm{H}_{\mathrm{P}}{ }^{-}$transgenic mice and the variability of the transcriptional effect of the $\mathrm{H}_{\mathrm{P}}{ }^{-}$mutation, however, does not allow us to determine the precise functional importance of this site for $\mu$ gene expression in skeletal muscle.

In conclusion, the OCTA site in the promoter is required for $\mu$ gene expression only in lymphoid tissues but not in skeletal muscle, confirming its role as an important determinant of lymphoid-specific gene expression. In contrast, the OCTA site in the enhancer is virtually dispensable for gene expression in both tissues, suggesting either that the $\mathrm{O}_{\mathrm{E}}{ }^{-}$mutant enhancer retains full activity because of a functional redundancy of its factor-binding sites or that other regulatory sequences in the gene can compensate for the mutated enhancer.

\section{An intragenic muscle-specific control region in the $\mu$ gene}

The OCTA independence of $\mu$ transgene expression in skeletal muscle suggests that the gene contains other regulatory sequences that allow for a high-level expression of the $\mathrm{O}_{\mathbf{p}}{ }^{-}$mutant transgene in this tissue. Because these regulatory sequences may also be involved in the expression of the unrearranged endogenous $\mu$ gene in skeletal muscle, we searched for them in the large intron preceding the $c_{\mu}$ constant region. To examine whether such sequences reside within the intragenic enhancer, we deleted from the intact $\mu$ gene the $0.6-\mathrm{kb} S c a \mathrm{I}-E c o \mathrm{RI}$ DNA fragment comprising all nuclear factor-binding sites as detected by in vivo footprinting of genomic DNA (Ephrussi et al. 1985) ( $\Delta 12 / 18$; Fig. 4A). Three transgenic mouse lines carrying the mutant $\Delta 12 / 18 \mu$ transgene did not express the gene at any detectable level in lymphoid tissues (Fig. 4B), confirming the complete dependence of $\mu$ gene transcription on the enhancer. Surprisingly, expression of the mutant transgene in skeletal muscle of mouse line 313 was reduced only twofold and, in lines 301 and 327, fourfold. This indicates that $\mu$ gene expression in this tissue is largely independent of the IgH enhancer.

Another mutant was generated by deleting a $2.9-\mathrm{kb}$ $H p a I-X b a I$ DNA fragment located $3^{\prime}$ of the IgH enhancer $(\Delta 25 / 54$, Fig. 4A). This deletion had little effect on transgene expression in spleen and thymus of mouse lines 210 and 222 (Fig. 4B). However, transgene expression in skeletal muscle was reduced 50-fold to a level similar to that detected in most other nonlymphoid tissues (see Figs. $4 \mathrm{~B}$, and 5). From these data, we conclude that this intragenic control region allows for $\mu$ gene expression in the absence of lymphoid-specific regulators and independent of the IgH enhancer and the OCTA site in the promoter. Thus, distinct and nonoverlapping regulatory sequences govern $\mu$ transgene expression in lymphoid tissues and skeletal muscle.

The $\mu$ enhancer is functional in many but not all nonlymphoid tissues.

In addition to the high-level expression in lymphoid tis- 


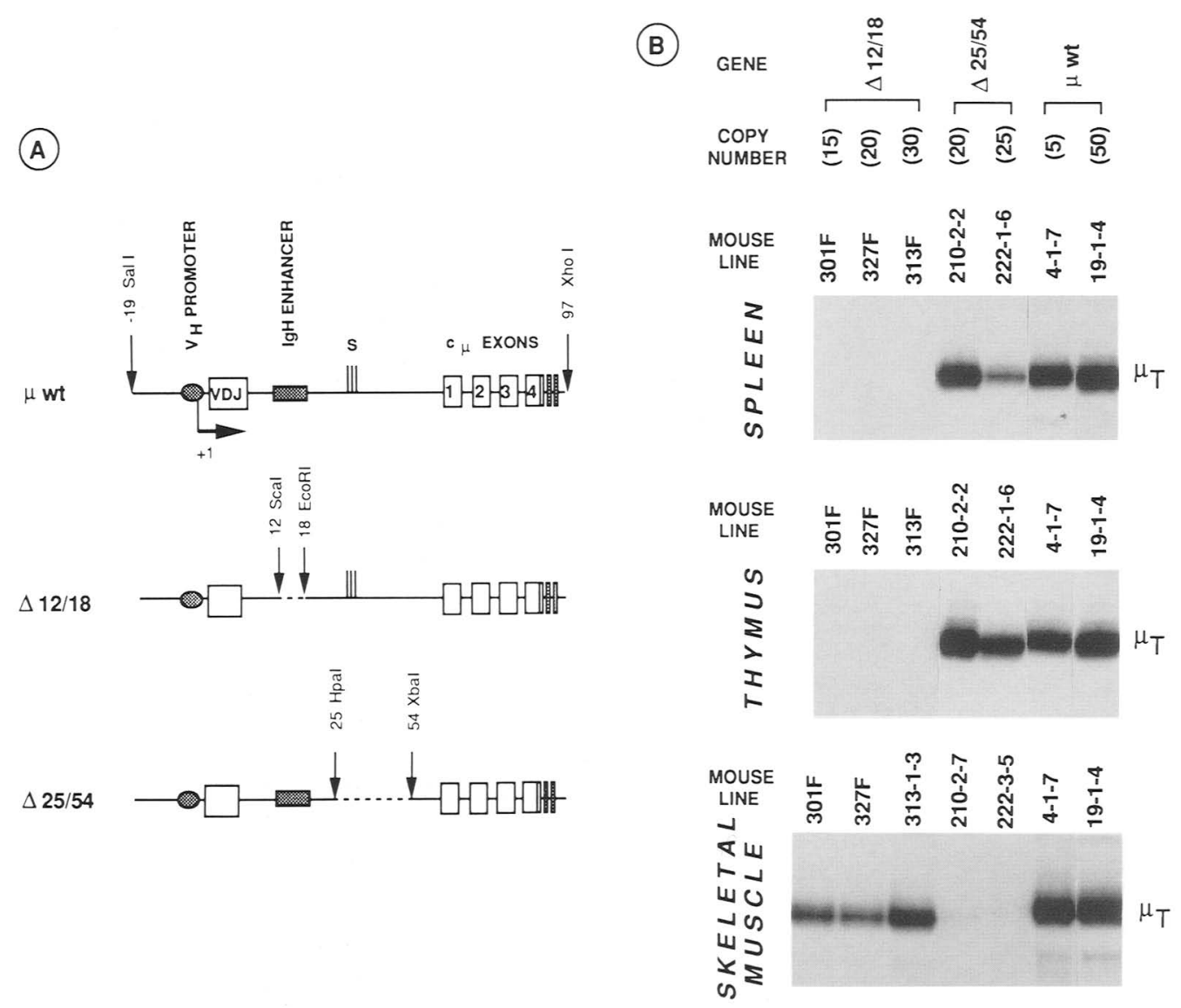

Figure 4. Identification of an intragenic muscle-specific control region. $(A)$ Structure of internal deletions. The mutation $\Delta 12 / 18$ deletes a 0.6-kb $S c a I-E c o$ RI DNA fragment comprising the enhancer from the $\mu$ gene. The numbers of the mutation refer to onehundredth of the nucleotide positions of the $5^{\prime}$ and $3^{\prime}$ boundary of the deletion with respect to the mRNA start site as +1 (see also Fig. 1). The mutation $\Delta 25 / 54$ deletes a 2.9-kb HpaI-XbaI DNA fragment 3 ' of the intragenic $\mu$ enhancer. (B) S1 nuclease protection assay detecting $\mu_{\mathrm{T}}$ transcripts in $3 \mu \mathrm{g}$ of total RNA from spleen, thymus, and skeletal muscle of mice carrying wild-type or mutated $\mu$ transgenes. The integrity and quantity of the RNA preparations from spleen and thymus were confirmed by $S 1$ nuclease protection assay with a probe detecting endogenous $m b-1$ or $\kappa$ transcripts as described in Fig. 3 (data not shown). Adjusting for the numbers of $m b-1$ transcripts as control, the numbers of transgenic $\mu_{\mathrm{T}}$ transcripts in spleen RNA from mice 210-2-2 and 222-1-6 appear to be under-represented by a factor of 5 .

sues and skeletal muscle, the wild-type $\mu$ transgene was expressed at a low level in several nonlymphoid tissues (mouse lines 4 and 19; Fig. 5). Quantitation of input total RNA was determined by UV spectrophotometry and confirmed by ethidium bromide staining of $18 \mathrm{~S}$ rRNA (data not shown). To control for blood and lymph node contamination, the various RNA samples were also hybridized with a $c_{\kappa}$ constant region probe detecting endogenous $\kappa$ transcripts (data not shown). $\kappa$ transcripts were absent in most of the RNA preparations from nonlymphoid tissues and were only detected at low levels in some RNA preparations from salivary glands. Expression of the $\mu$ transgene in kidney, brain, and salivary gland was demonstrated further by the analysis of the $\mathrm{O}_{\mathrm{P}}{ }^{-}$ mutant transgene. The $\mathrm{O}_{\mathrm{P}}{ }^{-}$mutation did not significantly affect $\mu$ transgene expression in these nonlymphoid tissues, whereas $\mu_{T}$ levels in spleen and thymus were drastically reduced (mouse lines 817 and 810; Fig.
5). The mutant $\Delta 25 / 54$ transgene, lacking the putative muscle-specific control region, is also expressed at a low level in skeletal muscle (mouse lines 210 and 222; Fig. 5). These expression patterns raise the question as to whether the intragenic $\mu$ enhancer may be active in nonlymphoid tissues.

We examined the function of the enhancer in nonlymphoid tissues by analyzing the expression of the $\Delta 12 / 18$ $\mu$ transgene in liver, kidney, brain, salivary gland, and skeletal muscle (mouse lines 301 and 313; Fig. 5). Neither of the two mouse lines analyzed expressed the enhancerless transgene in any of the tissues except in skeletal muscle. This suggests that the enhancer governs both the high-level expression in lymphoid tissues and the low-level expression in nonlymphoid tissues. In liver, however, no $\mu_{\mathrm{T}}$ transcripts can be detected in any of the transgenic mice indicating that the $\mu$ enhancer is nonfunctional in this tissue. The activity of the $\mu$ en- 


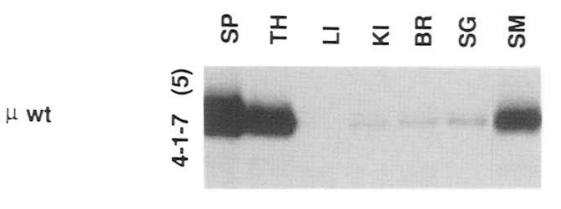

Figure 5. Tissue-specific pattern of expression of mutated $\mu$ transgenes. Sl nuclease protection assay detecting transgenic $\mu_{\mathrm{T}}$ transcripts in 12 $\mu \mathrm{g}$ of total RNA from spleen (SP), thymus (TH), liver (LI), kidney (KI), brain (BR), salivary gland (SG), and skeletal muscle (SM) of mice carrying a wild-type or a mutated $\mu$ transgene. For each transgene, two independent mouse lines were analyzed. To test for the presence of contaminating lymphocytes in the tissue preparations from kidney, brain, and salivary gland, SI nuclease protection assays with a $c_{\kappa}$ DNA probe detecting endogenous $k$ transcripts were performed (data not shown). Endogenous $\kappa$ transcripts were found only at low abundance in total RNA preparations from salivary glands of transgenic mice 19-1-4, 801-1-9, 604-1-1 and 631-1-1 and at higher abundance in the RNA preparation from salivary gland of mouse line 918-1-5. $\kappa$ transcripts were also present at low abundance in total RNA preparations from kidneys of transgenic mice 817-1-1, 918-1-5, and 631-1-3. The integrity and quantity of the RNA preparations from the various tissues were confirmed by staining of $18 \mathrm{~S}$ rRNA with ethidium bromide (data not shown).

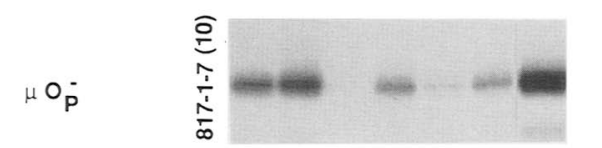

$\mu O_{\mathrm{P}}^{-} \mathrm{O}_{\mathrm{E}}^{-}$
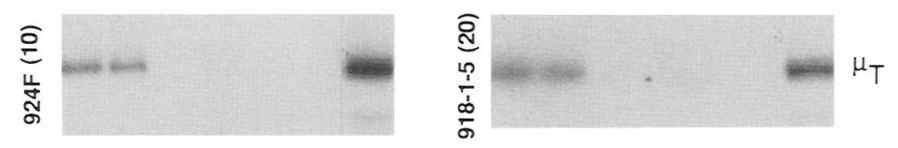

$\mu \mathrm{O}_{\mathrm{E}}^{-}$
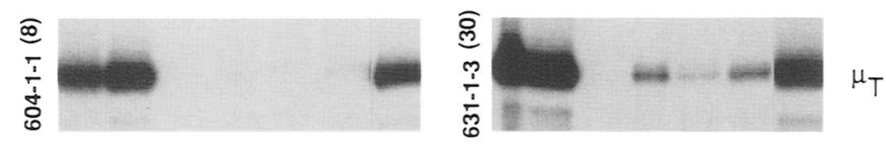

$\Delta 12 / 18$
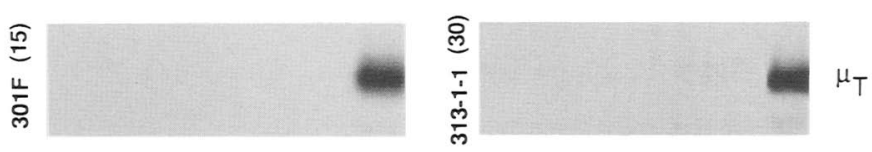

$\Delta 25 / 54$
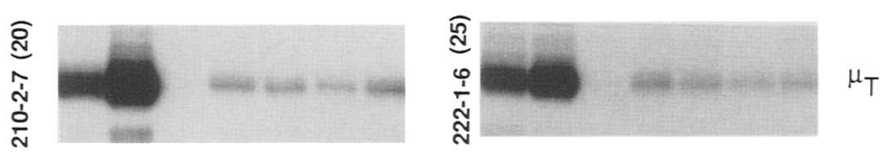

hancer in the other nonlymphoid tissues is demonstrated further by comparing the expression of the $\mathrm{O}_{\mathrm{P}}{ }^{-} \mathrm{O}_{\mathrm{E}}{ }^{-}$and $\mathrm{O}_{\mathrm{P}}{ }^{-}$mutant transgenes. In $\mathrm{O}_{\mathrm{P}}{ }^{-} \mathrm{O}_{\mathrm{E}}{ }^{-}$transgenic mice, no $\mu_{\mathrm{T}}$ transcripts could be detected in liver, kidney, brain, and salivary gland, and the number of transcripts in skeletal muscle was reduced two- to fivefold (mouse lines 924 and 918; Fig. 5). In contrast, the $\mathrm{O}_{\mathbf{P}}{ }^{-}$single mutation did not significantly affect $\mu$ transgene expression in nonlymphoid tissues (mouse lines 817 and 801 ; Fig. 5). The $\mathrm{O}_{\mathrm{E}}{ }^{-}$single mutation decreased $\boldsymbol{\mu}$-transgene expression specifically in the nonlymphoid tissues of mouse line 604; however, it did not affect transgene expression in mouse line 631. The molecular basis for the divergent transcriptional effect of this mutation is currently unclear. However, a consistent decrease of $\mu$ transgene expression in nonlymphoid tissues of transgenic mice is observed with a double mutation of both the $O_{E}$ and $\mu B$ site in the $\mu$ enhancer ( $T$. Jenuwein and R. Grosschedl, unpubl.). Taken together, these data suggest that the $\mu$ enhancer is functional in many but not all nonlymphoid tissues. Moreover, the OCTA site in the enhancer contributes to $\mu$ gene expression in nonlymphoid cells, which indicates that this site may be functionally distinct from the lymphoid-specific OCTA site in the promoter.

\section{Discussion}

Our study suggests that the tissue-specific expression pattern of the $\mu$ immunoglobulin gene is more complex than consisting of a simple on-state in lymphoid tissues and an off-state in all nonlymphoid tissues. We detect expression of a rearranged $\mu$ transgene and the endogenous $\mu$ locus not only in lymphoid tissues but also in skeletal muscle. In addition, we observe $\mu$ transgene expression at a low level in many but not all nonlymphoid tissues. Therefore, transgene expression, falls into four categories (for schematic summary of the data, see Fig. 6). First, expression in lymphoid tissues at a high level is dependent on the intragenic enhancer and the OCTA site in the promoter. Second, expression in skeletal muscle is detected at a level comparable to that in lymphoid tissues and is governed by a muscle-specific control region (MCR) located $3^{\prime}$ of the enhancer. Both the enhancer and the OCTA site in the promoter are virtually dispensable for $\mu$ gene expression in skeletal muscle. Although the $\mu$ enhancer is nonessential for transgene expression in skeletal muscle, it appears to be functional (see below for discussion). Third, expression at a 50-fold lower level is observed in brain, kidney, and salivary gland. This low-level expression is dependent on the $\mu$ enhancer but is independent of the OCTA site in the promoter. Therefore, the enhancer is found to be functional in several nonlymphoid tissues, although its activity in lymphoid tissues appears to be 3- to 10-fold higher, possibly due to a lymphoid-specific sequence element (LSE) (see below for discussion). Fourth, liver and embryonic fibroblast cells do not express the transgene 


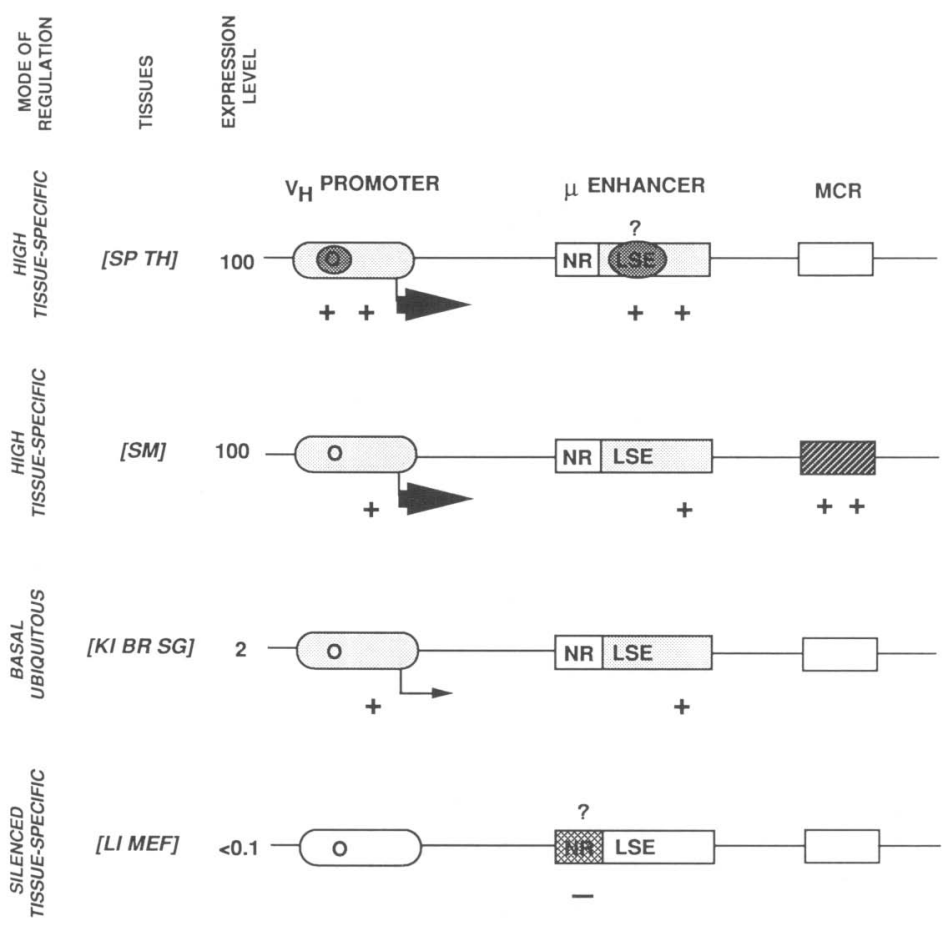

Figure 6. Schematic summary of the regulation of $\mu$ transgene expression. Transcriptional control regions of the $\mu$ gene are indicated by boxes. Functionality of regulatory sequences is represented by shading. Positively or negatively acting transcriptional control regions are indicated by + or - , respectively. The OCTA site in the $\mathrm{V}_{\mathrm{H}}$ promoter is shown as $\mathrm{O}$, the putative lymphoid-specific element(s) in the $\mu$ enhancer as LSE, and the muscle-specific control region as MCR. Dark shading of these symbols represents the tissue-specific function of the regulatory sequences. Putative negative regulatory sequences (NR), indicated by a hatched box, are only functional in liver and embryonic fibroblasts. The question marks above LSE and NR indicate that their precise identity is currently unknown. The abbreviation of the tissues is the same as in Fig. 1. at any detectable level and appear to represent a true off-state of the gene. Active repression of enhancer function by negative regulatory elements (NR), previously identified in tissue culture (Kadesch et al. 1986; Imler et al. 1987; Weinberger et al. 1988; Scheuermann and Chen 1989), may prevent $\mu$ transgene expression in these tissues.

\section{OCTA-dependent and OCTA-independent $\mu$ gene transcription}

Transcription of the rearranged $\mu$ transgene in lymphoid tissues of transgenic mice is largely dependent on the OCTA site in the promoter. In contrast, the mutation of the OCTA site in the promoter has virtually no effect on transcription in any of the analyzed nonlymphoid tissues. Our data do not distinguish between a nonfunctional and a nonessential $\mathrm{O}_{\mathrm{P}}$ site in nonlymphoid tissues. However, the observation that both the high-level expression of the $\mu$ gene in skeletal muscle and the lowlevel expression in other nonlymphoid tissues are independent of the $\mathrm{O}_{P}$ site argues for a lack of function rather than a functional redundancy.

The question arises as to whether the difference in the OCTA-dependent promoter function in lymphoid versus nonlymphoid tissues can be explained in the framework of the tissue distribution and transcriptional activation potential of Oct-1 and Oct-2. The OCTA-independent promoter function in skeletal muscle suggests that the ubiquitous Oct-1 protein by itself is not sufficient to stimulate promoter activity. Oct-2, by itself, however, may also be insufficient to account for lymphoid-specific expression. Recent observations indicated that the expression of the endogenous $\mu$ gene in tissue culture cells does not correlate with the abundance of Oct- 2 protein (Cockerill and Klinken 1990). Likewise, the OCTA dependence of $\mu$ transgene expression in spleen and thymus is similar, despite a large difference in the abundance of Oct-2. Analysis of nuclear extracts from rat spleen and thymus for the presence of Oct proteins by electrophoretic mobility-shift assays indicated that Oct2 can be detected in thymus at $\sim 5 \%$ of the level detected in spleen (A. Amsterdam and R. Grosschedl, unpubl.). Taken together, these data can, in principle, be accounted for by at least two explanations. First, a small or even an undetectable amount of Oct- 2 is sufficient for conferring OCTA-dependent promoter function. We consider this as unlikely because the dependence of $\mu$ transgene expression on a functional $\mathrm{O}_{\mathrm{p}}$ site increases during B-cell differentiation and by stimulation of splenocytes with bacterial lipopolysaccharide (T. Jenuwein and R. Grosschedl, unpubl.). Both of these conditions were shown previously to increase the abundance of Oct2 (Staudt et al. 1986). Instead, we favor a second view according to which an interaction of the ubiquitous Oct1 protein with a putative lymphoid-specific factor would enhance the potential of Oct-1 at stimulating transcription from the $\mathrm{V}_{\mathrm{H}}$ promoter in spleen and thymus. For example, the interaction between the viral protein VP16 and Oct- 1 results in the formation of a complex that is more effective at stimulating transcription from a reporter gene containing an OCTA-related binding site than Oct-1 itself (Stern et al. 1989). According to this scheme, Oct-1 in combination with the putative lymphoid-specific activator would govern OCTA-dependent 
promoter function in unstimulated or immature B lymphocytes and in T lymphocytes, whereas Oct-2 would up-regulate $\mathrm{V}_{\mathrm{H}}$ promoter function during B-cell differentiation and upon cell stimulation.

Another question arises as to the functional role of the OCTA site in the $\mu$ enhancer. The OCTA site in the $\mu$ enhancer $\left(O_{E}\right)$ is dispensable for expression in both lymphoid tissues and skeletal muscle. In other nonlymphoid tissues, however, this site appears to be involved in lowlevel $\mu$ transgene expression. The contribution of the $\mathrm{O}_{E}$ site to basal $\mu$ enhancer function is most evident in the context of a mutant $\mathrm{O}_{\mathrm{p}}{ }^{-}$promoter and in tissues that lack lymphoid- or muscle-specific regulators. Possibly, functional differences of the $\mathrm{O}_{E}$ and $\mathrm{O}_{P}$ sites result from the binding of distinct Oct proteins. Consistent with this interpretation, OCTA-binding proteins, different from Oct-1, have been identified in nuclear extracts from several nonlymphoid tissues (Schöler et al. 1989). Moreover, biochemical evidence suggests that the $\mathrm{O}_{\mathrm{E}}$ site, but not the $\mathrm{O}_{\mathrm{P}}$ site, can interact with a protein, termed Oct-2B, which is related to Oct- 2 but gives a distinct trypsin digestion pattern (Schreiber et al. 1988; Müller-Immerglück et al. 1990|.

\section{IgH enhancer function in multiple cell types}

With the exception of skeletal muscle, transcription of the rearranged $\mu$ gene is completely dependent on enhancer sequences. Previous transfection experiments indicated that the IgH enhancer is functional in lymphoid cell types but not in fibroblastic cells (Banerii et al. 1983; Gillies et al. 1983; Lenardo et al. 1987). Our transgenic mouse experiments extend the analysis of IgH enhancer function to other cell types as well and indicate that the $\mu$ enhancer not only governs gene expression in lymphoid tissues but also in many nonlymphoid tissues.

The activity of the enhancer, however, appears to be 3to 10 -fold higher in lymphoid tissues than in brain, kidney, and salivary gland, as determined by the different expression levels of the $\mathrm{O}_{\mathrm{P}}{ }^{-}$transgene in mouse lines 817 and 801 . This tissue specificity is even more pronounced with $\mathrm{O}_{\mathrm{P}}{ }^{-} \mathrm{O}_{\mathrm{E}}{ }^{-}$transgenes, suggesting that other putative regulatory sequences, in addition to the OCTA sites, contribute to lymphoid specificity of $\mu$ gene expression. Although the identity of these sequences, referred to as LSEs (see Fig. 6), is currently unknown, they are likely to reside in the $\mu$ enhancer. One candidate for the LSE is the $\mu \mathrm{B}$ site, which recently has been shown to confer B-cell-specific expression on a heterologous gene (Libermann et al. 1990; Nelsen et al. 1990). However, it is unlikely that this site is the only LSE, because a mutant $\mu$ transgene that lacks both a functional OCTA site and $\mu \mathrm{B}$ site in the enhancer is expressed in lymphoid tissues of two transgenic mouse lines at a level similar to the wild-type gene ( $T$. Jenuwein and R. Grosschedl, unpubl.). Other sequences in the $\mu$ enhancer, such as the E2/E3 boxes (Cook and Neuberger 1990), or the recently identified $\pi$ box (Libermann et al. 1990), may also contribute to lymphoid-specific gene expression.

Although the $\mu$ enhancer does not appear to be re- quired for transgene expression in skeletal muscle, the enhancer is functional on the basis of the following observations: First, expression of the $\Delta 25 / 54$ transgene was decreased in skeletal muscle to a low level, similar to that detected in the other nonlymphoid tissues. Because the $\Delta 25 / 54$ mutation affected $\mu$ transgene expression only in skeletal muscle, this indicates a tissue-specific function of the deleted regulatory sequences. Second, a deletion mutant that lacks both the IgH enhancer and the muscle-specific control region is not expressed at any detectable level in this tissue (A. Darveau and R. Grosschedl, unpubl.).

The transcriptionally inactive state of the $\mu$ transgene in liver and fibroblastic cells raises the question as to whether the enhancer is nonfunctional or repressed in these cell types. Previous transfection experiments demonstrated that the lack of $\mu$ enhancer function in fibroblasts is due, at least in part, to negatively acting regulatory sequences located adjacent to the enhancer (Imler et al. 1987; Scheuermann and Chen 1989) or located between the E1 and E2 motif (Weinberger et al. 1988). In addition, sequences that contribute to enhancer function in lymphoid tissues, such as the OCTA site, the $\mu \mathrm{B}$ site, and the E5/E2 box, were also shown to be targets for negative regulation (Yu et al. 1989; Henthorn et al. 1990; Libermann et al. 1990). Whatever sequences govern the negative control of enhancer function, our analysis in transgenic mice indicates that the transcriptionally inactive state of the $\mu$ transgene is restricted to specific nonlymphoid cell types.

\section{Complex tissue specificity of $\mu$ gene expression}

In this study we show that both the endogenous $\mu$ gene locus and a rearranged $\mu$ transgene are expressed in lymphoid tissues and in skeletal muscle. Furthermore, we have identified an intragenic region in the $\mu$ gene that governs high-level expression of the $\mu$ transgene in skeletal muscle. This pattern of tissue-specific expression of the $\mu$ gene is more complex than that anticipated from previous observations. Mouse germ-line transformations with murine $\mu$ genes linked to bacterial plasmid sequences did not exhibit transgene expression in skeletal muscle (Grosschedl et al. 1984; R. Grosschedl, unpubl.). Possibly, plasmid sequences interfere with $\mu$ gene expression in skeletal muscle. Indeed, bacterial plasmid sequences have been shown to inhibit the expression of a microinjected skeletal muscle actin gene in transgenic mice (Shani 1986)

The biological significance of a MCR located in the immunoglobulin $\mu$ gene is unclear. It is unlikely that the endogenous $c_{\mu}$ transcripts in skeletal muscle are translated because similar transcripts that are generated from the unrearranged $\mu$ gene in $B$ and $T$ lymphocytes fail to give rise to protein (Nelson et al. 1983; Lennon and Perry 1985). Moreover, the broad range in the abundance of $c_{\mu}$ transcripts in skeletal muscle of different mouse strains seems to be inconsistent with an important biological role for these transcripts. Possibly, the intragenic MCR directs muscle-specific expression of a distinct gene 
nested within the immunoglobulin heavy-chain locus. This gene-within-a-gene arrangement has now been observed for several gene loci (Levinson et al. 1990; Viskochil et al. 1990).

The presence of endogenous $c_{\mu}$ transcripts in skeletal muscle indicates a lack of stringent control of lymphoid specificity of transcription. However, in the absence of functional gene rearrangement, no $\mu$ protein can be synthesized. Thus, the control of immunoglobulin gene rearrangement appears to provide another mechanism to confer cell type specificity on the $\mu$ gene. Recently, the RAG- 1 and RAG-2 genes, which are involved in the rearrangement of immunoglobulin genes, were shown to be expressed only in lymphocytes (Oettinger et al. 1990). From the previous observation of high-level expression of a rearranged $\mu$ transgene in thymus, we concluded that rearrangement plays an important role in determining the B- versus $\mathrm{T}$-lymphocyte specificity of expression (Grosschedl et al. 1984). We can now extend the role of gene rearrangement as an important restrictive process for cell type-specific immunoglobulin gene expression to nonlymphoid tissues as well.

In conclusion, our study of the regulation of $\mu$ transgene expression suggests that the $\mu$ gene has a ubiquitous competence for transcription, as evidenced by lowlevel expression in many tissues. This basal expression is up-regulated in lymphoid and muscle tissues by distinct regulatory sequences. Moreover, putative negative sequence elements may be necessary to down-regulate the basal expression and to confer the inactive transcriptional state that is observed only in specific cell types. Thus, the plethora of regulatory information appears to be required for directing the complex tissue-specific expression pattern of the $\mu$ gene in the whole animal.

\section{Materials and methods}

\section{Construction of point mutations}

The DNA construct $(\mathrm{p} \mu)$ harboring the rearranged wild-type $\mu$ gene has been described (Grosschedl et al. 1984). For the generation of point mutations in the various Oct-binding sites, the $X b a I-E c o R I$ DNA fragment comprising the $\mu$ enhancer (Fig. 2) between nucleotide position +1085 and +1765 relative to the transcription start site or the HindIII-EcoRV DNA fragment containing $\mathrm{V}_{\mathrm{H}}$ promoter sequences (Fig. 2) between nucleotide position -950 and -18 was subcloned into the polylinker of Bluescript M13KS - and Bluescript M13KS + (Stratagene), respectively. Site-directed mutagenesis was accomplished by a modification of the method of Kunkel (1985). Plasmid DNA was transformed into Escherichia coli strain CJ236. Coinfection with bacteriophage M13R 408 resulted in the production of single-stranded uracil-containing plasmid DNA. Oligonucleotides containing the desired point mutations in the Oct-binding sites were annealed to the single-stranded plasmid DNA and used as primers for synthesis of the second strand. The DNA was transformed into E. coli strain HB101, and mutants were identified by sequencing supercoiled DNA obtained from individual transformants. For each mutation procedure, $\geqslant 50 \%$ of transformants carried a mutated plasmid. The mutated enhancer and promoter DNA fragments were then transferred into $\mathrm{p} \mu$, and the presence of the mutated factor-binding sites was confirmed by sequenc- ing the respective regions of interest in the final DNA construct.

\section{Construction of deletion mutations}

To generate the $\mu$ enhancer deletion mutant $\Delta 12 / 18$, the Eco-RV-SacI fragment from $\mathrm{p} \mu$, comprising the rearranged VDJ variable region and the intragenic $\mu$ enhancer (Fig. 2) between nucleotide positions -18 and +2592 , was subcloned into the polylinker of Bluescript M13KS + (Stratagene). The recombinant DNA was cleaved with EcoRV and ScaI, and the fragment between nucleotide positions -18 to +1236 was isolated. This

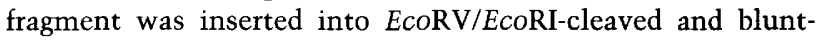
ended $\mu$ vector DNA and analyzed for its correct orientation. The resulting DNA construct lacks $\mu$ enhancer sequences between nucleotide position +1236 to +1765 (Fig. 4).

To generate the deletion mutant $\Delta 25 / 54$, the EcoRI-BamHI fragment from $\mathrm{p} \mu$, containing intragenic and $\mu$ constant region exon sequences (Fig. 2) between nucleotide positions +1765 and +6430 , was subcloned into the polylinker of Bluescript M13KS + (Stratagene). The recombinant DNA was cleaved with $X b a I$, the $5^{\prime}$ ends were filled in with Klenow DNA polymerase (Boehringer Mannheim), and the DNA was digested further with BglII. The fragment between nucleotide positions +5375 to +6120 was isolated. This fragment was inserted into Hpal/ $B g$ III-cleaved $\mu$ vector DNA. The resulting DNA construct lacks $\mu$ intragenic sequences between nucleotide positions +2586 to +5375 (Fig. 4).

\section{Generation of transgenic mice}

Plasmids containing the rearranged $\mu$ gene were cut with SalI and $X h o l$, and the $\mu$ gene insert was purified from bacterial vector sequences by gel electrophoresis. Linear $\mu$ DNA was diluted to $3 \mu \mathrm{g} / \mathrm{ml}$ and introduced into the germ line of mice by microinjection of fertilized C57BL $6 \times$ SJL $\mathrm{F}_{2}$ mouse eggs as described (Hogan et al. 1986). Transgenic mice were identified by blot analysis of tail DNA. On the average, $\sim 15 \%$ of babies born were transgenic.

\section{RNA analysis}

For the detection of transgenic $V_{H}$ transcripts $\left(\mu_{T}\right), 3$ or $12 \mu \mathrm{g}$ of total RNA, isolated from various tissues as described (Grosschedl et al. 1984), was hybridized in the presence of carrier RNA (final amount of RNA adjusted to $15 \mu \mathrm{g}$ ) at $37^{\circ} \mathrm{C}$ with a single-stranded, ${ }^{32} \mathrm{P}-5^{\prime}$-end-labeled DNA probe. Quantitation of total RNA was determined by UV spectrophotometry and confirmed by ethidium bromide staining of $18 \mathrm{~S}$ rRNA. The DNA probe was prepared by extending an oligonucleotide primer complimentary to nucleotide sequences between +45 and +62 from the RNA 5 ' end with Klenow DNA polymerase (Boehringer Mannheim). RNA-DNA hybrids were digested with 20 units of $\mathrm{S} 1$ nuclease (Pharmacia) at $37^{\circ} \mathrm{C}$, and the protected 62 bp nucleotide fragment was separated on a sequencing gel and visualized by autoradiography. Quantitation of RNA levels was determined by densitometric scanning of autoradiograms. The RNA analysis by S1 nuclease protection assays was performed multiple times with each sample.

For the detection of endogenous $c_{\mu}$ transcripts, $6 \mu \mathrm{g}$ of total RNA was hybridized in the presence of $6 \mu \mathrm{g}$ of carrier RNA at $48^{\circ} \mathrm{C}$ with a strand-separated, ${ }^{32} \mathrm{P}-5^{\prime}$-end-labeled DNA fragment comprising the exon/intron boundary of the first $\mu$ constant region exon. The probe for the detection of endogenous $\kappa$ transcripts was a strand-separated, ${ }^{32} \mathrm{P}-5^{\prime}$-end-labeled DNA fragment comprising sequences from the $\kappa$ constant region exon. 
The probe for the detection of endogenous $m b-1$ transcripts was a ${ }^{32} \mathrm{P}-5$ '-end-labeled DNA fragment protecting nucleotide positions from +3 to +245 of the $m b$-1 gene (Sagakuchi et al. 1988).

For the RNA blot analysis, $12 \mu \mathrm{g}$ of total RNA was separated on a $1.2 \%$ agarose- $-2.2 \mathrm{M}$ formaldehyde gel in the presence of ethidium bromide at $2 \mu \mathrm{g} / \mathrm{ml}$. The RNA was transferred to a nylon filter and hybridized with a ${ }^{32} \mathrm{P}$-labeled nick-translated DNA probe comprising the first $\mu$ constant region exon. RNADNA hybrids were visualized by autoradiography.

\section{Acknowledgments}

We thank Dr. Meinrad Busslinger for providing nuclear extracts of rat spleen and thymus. We are grateful to members of our laboratory and to Drs. Bill Forrester, Douglas Hanahan, Alexander Johnson, and Keith Yamamoto for thoughtful comments on the manuscript. During the major part of this work, T.J. was the recipient of a fellowship from the Deutsche Forschungsgemeinschaft and is currently supported by a special fellowship from the Leukemia Society of America. This work was supported by a grant from the National Institute of Health to R.G.

The publication costs of this article were defrayed in part by payment of page charges. This article must therefore be hereby marked "advertisement" in accordance with 18 USC section 1734 solely to indicate this fact.

\section{References}

Araki, K., H. Maeda, P. Wang, P. Kitamura, and T. Watanabe. 1988. Purification of a nuclear trans-acting factor involved in the regulated transcription of a human immunoglobulin heavy-chain gene. Cell 53: 723-730.

Banerii, J., J. Olson, and W. Schaffner. 1983. A lymphocyte-specific cellular enhancer is located downstream of the joining region in immunoglobulin heavy chain genes. Cell 33: 729740 .

Beckmann, H., L.-K. Su, and T. Kadesch. 1990. TFE3: A helixloop-helix protein that activates transcription through the immunoglobulin enhancer $\mu \mathrm{E} 3$ motif. Genes \& Dev. 4: 167179.

Blackwell, T.K. and F.W. Alt. 1988. Immunoglobulin genes. In Molecular immunology (ed. B.D. Hames and D.M. Glover), pp. 1-60. IRL Press, Washington, D.C.

Calame, K. 1989. Immunoglobulin gene transcription: Molecular mechanisms. Trends Genet. 25: 395-399.

Cockerill, P.N. and S.P. Klinken. 1990. Octamer-binding proteins in diverse hemopoietic cells. Mol. Cell. Biol. 10: 12931296.

Cook, G.P. and M.S. Neuberger. 1990. Lymphoid-specific transcriptional activation by components of the $\operatorname{IgH}$ enhancer: Studies on the E2/E3 and octanucleotide elements. Nucleic Acids Res. 18: 3564-3571.

Ephrussi, A., G.M. Church, S. Tonegawa, and W. Gilbert. 1985. B lineage-specific interactions of an immunoglobulin enhancer with cellular factors in vivo. Science 227: 134-138.

Fletcher, C., N. Heintz, and R.G. Roeder. 1987. Purification and characterization of OTF-1, a transcription factor regulating cell cycle expression of a human histone $\mathrm{H} 2 \mathrm{~b}$ gene. Cell 51: 773-781.

Gillies, S.D., S. Morrison, V. Oi, and S. Tonegawa. 1983. A tissue-specific transcription enhancer element is located in the major intron of a rearranged immunoglobulin heavy chain gene. Cell 33: 717-728.

Grosschedl, R., D. Weaver, D. Baltimore, and F. Constantini. 1984. Introduction of a $\mu$ immunoglobulin gene into the mouse germ line: Specific expression in lymphoid cells and synthesis of functional antibody. Cell 38: 647-658.

Grosschedl, R. and D. Baltimore. 1985. Cell-type specificity of immunoglobulin gene expression is regulated by at least three DNA sequence elements. Cell 41: 885-897.

Henthorn, P., M. Kiledjian, and T. Kadesch. 1990. Two distinct transcription factors that bind the immunoglobulin enhancer $\mu \mathrm{E} 5 / \mathrm{kE} 2$ motif. Science 247: 467-470.

Herskowitz, I. 1989. A regulatory hierarchy for cell specialization in yeast. Nature 342: 749-757.

Hogan, B.L.M., F. Constantini, and E. Lacy. 1986. Manipulating the mouse embryo: A laboratory manual. Cold Spring Harbor Laboratory, Cold Spring Harbor, New York.

Imler, J.-L., C. Lemaire, C. Wasylyk, and B. Wasylyk. 1987. Negative regulation contributes to tissue specificity of the immunoglobulin heavy-chain enhancer. Mol. Cell. Biol. 7: 25582567.

Johnson, D.G., L. Caraynnopoulos, J.D. Capra, P.W. Tucker, and J.H. Hanke. 1990. The ubiquitous octamer-binding protein(s) is sufficient for transcription of immunoglobulin genes. Mol. Cell. Biol. 10: 982-990.

Kadesch, T., P. Zervos, and D. Ruezinski. 1986. Functional analysis of the murine IgH enhancer: Evidence for negative control of cell-type specificity. Nucleic Acids Res. 14: 82098221.

Kemler, I., E. Schreiber, M.M. Muller, P. Matthias, and W. Schaffner. 1989. Octamer transcription factors bind to two different sequence motifs of the immunoglobulin heavychain promoter. EMBO I. 8: 2001-2008.

Kemp, D.J., A.W. Harris, S. Corey, and J.M. Adams. 1980. Expression of the immunoglobulin $\mathrm{c}_{\mu}$ gene in mouse $\mathrm{T}$ and $\mathrm{B}$ lymphoid and myeloid cell lines. Proc. Natl. Acad. Sci. 77: 2876-2880.

Kunkel, T. A. 1985. Rapid and efficient site-specific mutagenesis without phenotypic selection. Proc. Natl. Acad. Sci. 82: 488-492.

Kurosawa, Y., H. Von Boehmer, W. Haas, H. Sakano, A. Traunecker, and S. Tonegawa. 1981. Identification of $D$ segments of immunoglobulin heavy chain genes and their rearrangement in T lymphocytes. Nature 290: 565-570.

Landolfi, N.F., X.-M. Yin, J.D. Capra, and P.W. Tucker. 1988. A conserved heptameric sequence upstream of the IgH promoter region octamer can be the site of a coordinant proteinDNA interaction. Nucleic Acids Res. 16: 5503-5515.

LeBowitz, J.H., T. Kobayashi, L. Staudt, D. Baltimore, and P.A. Sharp. 1988. Octamer-binding proteins from B or HeLa cells stimulate transcription of the immunoglobulin heavy-chain promoter in vitro. Genes \& Dev. 2: 1227-1237.

Lenardo, M., J.W. Pierce, and D. Baltimore. 1987. Protein-binding sites in immunoglobulin gene enhancers determine transcriptional activity and inducibility. Science 236: 15731577.

Lennon, G.G. and R.P. Perry. 1985. $\mathrm{C}_{\mu}$-containing transcripts initiate heterogeneously within the IgH enhancer region and contain a novel $5^{\prime}$ untranslatable exon. Nature 318: 475478.

Levinson, B., S. Kenwrick, D. Lakich, G. Hammonds, and J. Gitschier. 1990. A transcribed gene in an intron of the human factor VIII gene. Genomics 7: 1-11.

Libermann, T.A. and D. Baltimore. 1991. Transcriptional regulation of immunoglobulin gene expression. Mol. Aspects Cell. Regul. 6: 385-407.

Libermann, T.A., M. Lenardo, and D. Baltimore. 1990. Involvement of a second lymphoid-specific enhancer element in the regulation of immunoglobulin heavychain gene expression. Mol. Cell. Biol. 10: 3155-3162. 
Loh, D.Y., A. Bothwell, M.E. White-Scharf, T. Imanishi-Kari, and D. Baltimore. 1983. Molecular basis of a mouse strainspecific anti-hapten response. Cell 33: 85-93.

Mason, J.O., G.T. Williams, and M.S. Neuberger. 1985. Transcriptional cell type specificity is conferred by an immunoglobulin $\mathrm{V}_{\mathrm{H}}$ gene promoter that includes a functional consensus sequence. Cell 41: 479-487.

Mitchell, P.J. and R. Tjian. 1989. Transcriptional regulation in mammalian cells by sequence-specific DNA binding proteins. Science 245: 371-378.

Müller-Immerglück, M.M., W. Schaffner, and P. Matthias. 1990. Transcription factor Oct-2A contains functionally redundant activating domains and works selectively from a promoter but not from a remote enhancer position in non-lymphoid (HeLa) cells. EMBO I. 9: 1625-1634.

Murre, C., P. Schonleber McCaw, and D. Baltimore. 1989. A new DNA-binding and dimerization motif in immunoglobulin enhancer binding, daughterless, myoD, and myc proteins. Cell 56: 777-783.

Nelsen, B., T. Kadesch, and R. Sen. 1990. Complex regulation of the immunoglobulin $\mu$ heavy-chain gene enhancer: $\mu \mathrm{B}$, a new determinant of enhancer function. Mol. Cell. Biol. 10: $3145-3154$.

Nelson, K.J., J. Haimovich, and R.P. Perry. 1983. Characterization of productive and sterile transcripts from the immunoglobulin heavy-chain locus: Processing of $\mu_{\mathrm{m}}$ and $\mu_{\mathrm{s}}$ mRNA. Mol. Cell. Biol. 3: 1317-1332.

Neuberger, M.S. 1983. Expression and regulation of immunoglobulin heavy-chain genes transfected into lymphoid cells. EMBO I. 2: 1373-1378.

Nussenzweg, M.C., A.C. Shaw, E. Sinn, D.B. Danner, K.L. Holmes, H.C. Morse III, and P. Leder. 1987. Allelic exclusion in transgenic mice that express the membrane form of immunoglobulin $\mu$. Science 236: 816-819.

Oettinger, M.A., D.G. Schatz, C. Gorka, and D. Baltimore. 1990. RAG-1 and RAG-2, adjacent genes that synergistically activate V|D|J recombination. Science 248: 1517-1523.

Peterson, C.L., K. Orth, and K. Calame. 1986. Binding in vitro of multiple cellular proteins to immunoglobulin heavy-chain enhancer DNA. Mol. Cell. Biol. 6: 4168-4178.

Poellinger, L., B.K. Yoza, and R.G. Roeder. 1989. Functional cooperativity between protein molecules bound at two distinct sequence elements of the immunoglobulin heavychain promoter. Nature 337: 573-576.

Reth, M.G. and F.W. Alt. 1984. Novel immunoglobulin heavychain genes are produced from $\mathrm{DI}_{\mathrm{H}}$ gene segment rearrangements in lymphoid cells. Nature 312: 418-423.

Roman, C., J.S. Platero, J. Shuman, and K. Calame. 1990. Ig/ EBP-1: A ubiquitously expressed immunoglobulin enhancer binding protein that is similar to C/EBP and heterodimerizes with C/EBP. Genes \& Dev. 4: 1404-1415.

Sagakuchi, N., S.-I. Kashiwamura, M. Kimoto, P. Thalmann, and F. Melchers. 1988. B lymphocyte lineage-restricted expression of $m b-1$, a gene with CD3-like structural properties. EMBO I. 7: 3457-3464.

Scheidereit, C., A. Heguy, and R. Roeder. 1987. Identification and purification of a human lymphoid-specific octamerbinding protein (OTF-2) that activates transcription of an immunoglobulin promoter in vitro. Cell 51: 783-793.

Scheuermann, R.H. and U. Chen. 1989. A developmental-specific factor binds to suppressor sites flanking the immunoglobulin heavy-chain enhancer. Genes \& Dev. 3: 1255-1266.

Schöler, H.R., A.K. Hatzopoulos, R. Balling, N. Suzuki, and P. Gruss. 1989. A family of octamer-specific proteins present during mouse embryogenesis: Evidence for germline-specific expression of an Oct factor. EMBO /. 8: 2543-2550.
Schreiber, E., P. Matthias, M.M. Müller, and W. Schaffner. 1988. Identification of a novel lymphoid specific octamer binding protein (OTF-2B) by proteolytic clipping bandshift assay. EMBO I. 7:4221-4229.

Sen, R. and D. Baltimore. 1986. Multiple nuclear factors interact with the immunoglobulin enhancer sequences. Cell 46: 705716.

Shani, M. 1986. Tissue-specific and developmentally regulated expression of a chimeric actin-globin gene in transgenic mice. Mol. Cell. Biol. 6: 2624-2631.

Singh, H., J.H. LeBowitz, A.S. Baldwin, and P.A. Sharp. 1986. A nuclear factor that binds to a conserved sequence motif in transcriptional control elements of immunoglobulin genes. Nature 319: 154-158.

Staudt, L.M., H. Singh, R. Sen, T. Wirth, P.A. Sharp, and D. Baltimore. 1986. A lymphoid-specific protein binding to the octamer motif of immunoglobulin genes. Nature 323: 640643.

Staudt, L.M., R.G. Clerc, H. Singh, J.H. LeBowitz, P.A. Sharp, and D. Baltimore. 1988. Cloning of a lymphoid-specific cDNA encoding a protein binding the regulatory octamer DNA motif. Science 241: 577-580.

Stern, S., M. Tanaka, and W. Herr. 1989. The Oct-1 homeodomain directs formation of a multiprotein-DNA complex with the HSV transactivator VP16. Nature 341: 624-630.

Storb, U., C. Pinkert, B. Arp, P. Engler, K. Gollahon, J. Manoz, W. Brady, and R.L. Brinster. 1986. Transgenic mice with $\mu$ and $\kappa$ genes encoding anti-phosphorylcholine antibodies. $J$. Exp. Med. 164: 627-641.

Tanaka, M. and W. Herr. 1990. Differential transcriptional activation by Oct- 1 and Oct-2: Interdependent activation domains induce Oct-2 phosphorylation. Cell 60: 375-386.

Viskochil, D., A.M. Buchberg, G. Xu, R.M. Cawthon, J. Stevens, R.K. Wolff, M. Culver, J.C. Carey, N.G. Copeland, N.A. Jenkins, R. White, and P. O'Connell. 1990. Deletions and a translocation interrupt a cloned gene at the neurofibromatosis type 1 locus. Cell 62: 187-192.

Weinberger, J., P.S. Jan, and P.A. Sharp. 1988. Localization of a repressive sequence contributing to B-cell specificity in the immunoglobulin heavy-chain enhancer. Mol. Cell. Biol. 8: 988-992.

Wirth, T., L. Staudt, and D. Baltimore. 1987. An octamer oligonucleotide upstream of a TATA motif is sufficient for lymphoid-specific promoter activity. Nature 329: 174-178.

Yu, H., B. Porton, L. Shen, and L.A. Eckhardt. 1989. Role of the octamer motif in hybrid cell extinction of immunoglobulin gene expression: Extinction is dominant in a two enhancer system. Cell 58: 441-448. 


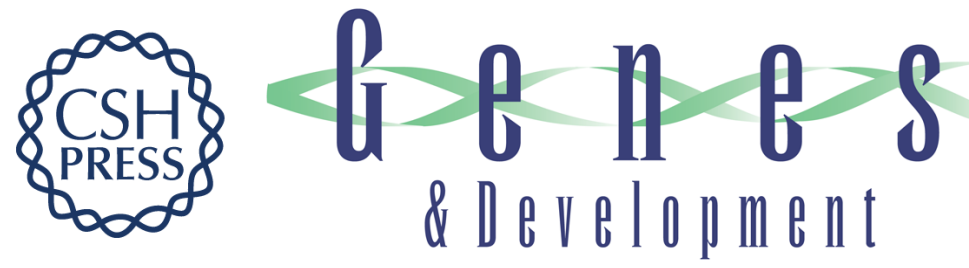

\section{Complex pattern of immunoglobulin mu gene expression in normal and transgenic mice: nonoverlapping regulatory sequences govern distinct tissue specificities.}

T Jenuwein and R Grosschedl

Genes Dev. 1991, 5:

Access the most recent version at doi:10.1101/gad.5.6.932

References This article cites 58 articles, 23 of which can be accessed free at: http://genesdev.cshlp.org/content/5/6/932.full.html\#ref-list-1

License

Email Alerting Receive free email alerts when new articles cite this article - sign up in the box at the top Service right corner of the article or click here.

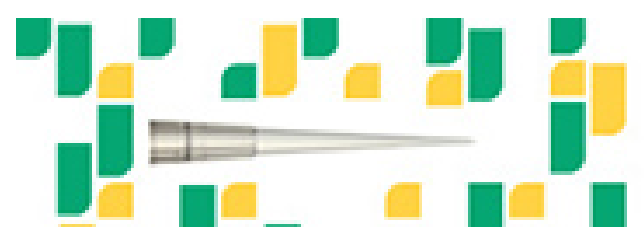

Focused on your science. 